\title{
The Diagnostic Potential of Dielectric Properties, Telomerase Activity and Cytokeratin 20 in Urine Cells of Bladder Cancer Patients
}

\author{
Fakhry F. Ibrahim ${ }^{1,3}$ and Magdy M. Ghannam ${ }^{2,4 *}$
}

${ }^{1}$ Department of Physics, College of Science, Shaqra University, Saudi Arabia

${ }^{2}$ Department of Physics and Astronomy, College of Science, King Saud University, Saudi Arabia

${ }^{3}$ Clinical Pathology Department, Cairo University Hospital, Cairo University, Egypt

${ }^{4}$ Department of Biophysics, Faculty of Science, Cairo University, Egypt

\section{Abstract}

Aim of the study: This work aims to search for markers suitable for the screening of bladder cancer, which should be specific, sensitive, reproducible, non-invasive and at acceptable cost.

Patients and methods: The study included 45 patients diagnosed as bladder cancer (30 TCC, 15 SCC) of different stages and grades, 20 patients with various urothelial diseases, besides 15 healthy volunteers of matched age and sex to the malignant group.

A random midstream urine sample was collected in a sterile container for the determination of telomerase by RT-PCR, keratin 20 by RT-PCR and immunohistochemical staining, urine cytology in addition to DNA dielectric properties.

Results: All parameters (telomerase, K20, cytology and DNA dielectric properties) for the malignant group showed significant difference from both the benign and the control groups. With respect to the grade, only K20 showed a significant positive correlation with grade in both TCC and SCC.

Conclusion: $\mathrm{K} 20$ is the best candidate as screening test for the diagnosis of bladder cancer, representing the highest sensitivity and specificity, beside the radiological and histopathological studies.

As a method, RT-PCR is superior to immunostaining for the detection of bladder cancer, meanwhile K20 immunohistochemistry $(\mathrm{IHC})$ results were much better than urine cytology as a bladder cancer screening test. Haematuria and inflammation reduced the specificity of telomerase assay, which reduced its validity as a tumor marker of bladder cancer. The studied DNA has a dielectric dispersion in the frequency range used. There is change in the electric properties of DNA of bladder cancer patients. The dielectric properties of DNA may be used as valuable supplementary markers in diagnosis of bladder cancer.

Keywords: Bladder cancer; Telomerase activity; Cytokeratin 20; Urine cells; RT PCR; Dielectrics

\section{Introduction}

In Western populations, bladder cancer is the $4^{\text {th }}$ most common malignant neoplasm in men and the $8^{\text {th }}$ in women. It occurs mostly due to smoking and exposure to aromatic amines and is a disease of the old with mean age of 75 years. It accounts for $6 \%$ and $2 \%$ of all cancers in males and females respectively, with a male/female ratio of $3: 1$ [1]. About $90 \%$ of all bladder tumors are Urothelial Cell Carcinomas (TCC), 5\% are Squamous Cell Carcinomas (SCC) and the remainder is rare tumors as adenocarcinoma, carcinosarcoma and sarcomatoid lesions [2].

In Egypt, bladder cancer for males accounts for $42.4 \%$ of all cancer cases, while in Females it accounts for $17.99 \%$, making it the leading cancers in Egyptian patients with a percentage of $32.67 \%$. Population was 195/1,000,000/year for males and 38/1,000,000/year for females [According to the NCI report of Cancer Distribution, NCI- Cairo University (1997)].

The gold standard for bladder cancer screening is still urinary cytology, as it is a non-invasive, safe and inexpensive. Although it is highly specific, the results are not reproducible and the interpretation is highly dependent on the skill of the operator. In addition, it exhibits variable sensitivities depending on tumor grade and cannot exclude the presence of malignancy [3]. This calls for the search of other markers for the screening of bladder cancer which should be specific, sensitive, reproducible, non-invasive and at acceptable cost.

Telomeres are protective structures that cap the ends of eukaryotic chromosomes and are composed of both repeated DNA elements and specific DNA-binding proteins. Telomeres are essential for maintaining genomic stability and loss of normal telomere function can lead to end-to-end fusions and chromosome loss by exonuclease digestion [4] Degradation of telomeres appears to constitute a signal with which a cell is no longer able to undergo cell division [5]. Telomerase, an RNAdependent DNA polymerase, maintains telomeric DNA. Telomerase synthesizes telomeric DNA sequences and almost universally provides the molecular basis for unlimited proliferative potential. Telomerase activity was found to be absent in most normal human somatic cells

*Corresponding author: Magdy M. Ghannam, Department of Physics and Astronomy, College of Science, King Saud University, Riyadh 11451 - P O Box: 2455, Saudi Arabia, Tel: +966509402550; Fax: +96614673656; E-mail: mmghanam@ksu.edu.sa, magdighannam@yahoo.com

Received June 03, 2012; Accepted July 28, 2012; Published July 30, 2012

Citation: Ibrahim FF, Ghannam MM (2012) The Diagnostic Potential of Dielectric Properties, Telomerase Activity and Cytokeratin 20 in Urine Cells of Bladde Cancer Patients. J Cancer Sci Ther 4: 237-242. doi:10.4172/1948-5956.1000148

Copyright: (c) 2012 lbrahim FF, et al. This is an open-access article distributed under the terms of the Creative Commons Attribution License, which permits unrestricted use, distribution, and reproduction in any medium, provided the original author and source are credited. 
but present in over $90 \%$ of cancerous cells and in vitro immortalized cells [6].

In humans, over $85 \%$ of malignant tumors express telomerase activity whereas most somatic tissues do not [7]. Increased telomerase activity strongly correlates with increased malignant potential and stage, in addition, genomic instability associated with loss of telomere sequences correlates with a late stage development of colonic carcinomas [8]. Telomerase especially helps in certain tumor types, where indeterminate cases are common, with general specificity of $91 \%$ and sensitivity of $85 \%$ [7].

Telomerase-based methods can be applied in body fluids and washes, making sample collection easier. This, however, might pose the difficulty of sampling error and the presence of infiltrating lymphocytes or other cells, giving false positive results [7]. For detection of bladder carcinoma in urine specimens, telomerase proved far more sensitive than cytology or other available screens. The sensitivity of telomerase RT-PCR assay ranged from $75.6 \%$ to $94 \%$, compared with $34 \%$ to $51 \%$ for routine cytology and the specificity ranges from $72 \%$ to $100 \%$ [9$12]$.

Cytokeratins $(40-70 \mathrm{kDa})$ are the major structural proteins in the cytoplasm of epithelial cells and their derivatives. They can be subdivided into two major types, I (acidic, K9-K20) and II (neutral / basic, K1-K8). Keratin filaments are built from lateral and longitudinal interactions involving types I-II heterodimers [13]. Each type of epithelial cells synthesizes at least one type I and one type II keratin, which co polymerize into filaments [14]. The organization of keratin filaments and their association with plasma membranes suggest that their principal function is structural to reinforce cells and to organize cells into tissues. Keratin filaments are characterized by tissue-specific expression patterns from early embryogenesis onwards, suggesting that these proteins are important in defining tissue structure and potential function [15]. Keratins also influence the availability of regulatory molecules such as apoptosis-inducing factors, heat shock proteins or signaling molecules affecting the sensitivity of cells to proliferative and apoptotic stimuli and play a role in cellular stress responses and drug resistance [16]. Keratin 20 (K20) is the most recently identified type I keratin protein of $46 \mathrm{KD}$, which shows a limited pattern of expression in normal tissues [17]. K20 is co-expressed along with K18 and K19 in the same intestinal cell types, which suggests that these three types I keratins may have redundant or complementary functions [18]

The expression of K20 in urothelium was restricted to superficial 'umbrella' cells even in the presence of severe inflammation. Only malignancy induced alteration in K20 expression pattern. It has been suggested that the pattern of K20 immunohistochemical staining is a useful adjunct to morphology in the diagnosis of urothelial dysplasia, since only malignant cells will show K20 immunostaining [19]. Because of the lack of immunological cross-reactivity with other cytokeratins, K20 has become an important tool for delineating the origin of metastatic human carcinomas arising from an unknown primary source [20]. Recently, several reports have suggested the use of a reverse transcription-polymerase chain reaction technique for the detection of K20 expression in exfoliated urine cells as a useful, noninvasive diagnostic test for urothelial carcinoma and premalignant urothelial lesions [21,22].

Dielectric properties of various biological materials have been previously investigated to get attractive information about their structural changes under any internal or external effects [23-25].
The main goal of the present work is to search for a suitable marker in order to screen bladder cancer, which should be specific, sensitive, reproducible, non-invasive and at acceptable cost.

\section{Materials and Methods}

The study included 80 subjects classified into three main groups:

I- Malignant Group: Includes 45 patients (35males and 10 females) with mean age of $60.9 \pm 9.6$ years, diagnosed as bladder cancer patients and confirmed by pathological

examination of the biopsies [26-28]. This group was further divided according to the type of tumor into two main subclasses:

1- Urothelial cell carcinoma (TCC) patients: 30 patients of grades I, II and III.

2- Squamous cell carcinoma (SCC) patients: 15 patients of grades I, II and III.

II- Benign Group: Includes 20 patients (15 males and 5 females) with mean age of $58.5 \pm 7.3$ years, with various non-malignant urothelial diseases including pyelonephritis and cystitis with and without stone formation.

III- Control Group: Including 15 apparently healthy people (12 males and 3 females) with mean age $56.5 \pm 6.1$ years, as normal and healthy controls.

All the patients of the malignant and benign groups involved in the study were chosen from those admitted to the Urology Department in the Faculty of Medicine Cairo University Hospitals between January 2010 and May 2010. All the patients of groups I and II were subjected to thorough clinical examination and history taken.

\section{Methods}

Specimen collection: A random midstream urine sample was collected from each patient in a sterile container. Each sample was divided into four aliquots: (1) $100 \mu$ laliquot was separated collectively for bacterial culture, (2) $1 \mathrm{ml}$ aliquot stored at $-80^{\circ} \mathrm{C}$ until used to extract DNA for the measurement of dielectric relaxation (3) 10-15 $\mathrm{ml}$ aliquot for urine cytology and keratin 20 immunostaining, and (4) the remaining urine sample was used for RT-PCR of telomerase and keratin 20. For aliquot 3, the cells shed in urine were separated by centrifugation at $4000 \mathrm{xg}$ for 10 minutes then slides were made for urine cytology and immunostaining. For aliquot 4 , cells shed in the urine were separated by centrifugation at $4000 \mathrm{xg}$ at $4^{\circ} \mathrm{C}$ for 10 minutes then washed in PBS then the cell pellet was stored at $-80^{\circ} \mathrm{C}$ until RTPCR was performed.

For all the specimens collected from all groups, the following was carried out:

I- RT-PCR: For the detection of telomerase and keratin 20 expression. The method involves:

1- Extraction of mRNA. The cells were dissolved in TRIzol ${ }^{\circ}$ Reagent (Invitrogen Life Technologies, U.S.A.), which is a monophasic solution of phenol and guanidium isothiocyanate. RNA was isolated according to the manufacturer's instructions and quantified spectrophotometrically.

2- RT-PCR. Reverse Transcription and PCR were carried out by a single-tube, singlestep Ready-to-Go RT-PCR Beads (Amersham Biosciences, U.S.A.), which utilize Moloney Murine Leukemia Virus 
Citation: Ibrahim FF, Ghannam MM (2012) The Diagnostic Potential of Dielectric Properties, Telomerase Activity and Cytokeratin 20 in Urine Cells of Bladder Cancer Patients. J Cancer Sci Ther 4: 237-242. doi:10.4172/1948-5956.1000148

(MMuLV) reverse transcriptase to synthesize first strand cDNA from RNA. For each of the three cDNAs to be amplified: telomerase, keratin 20 and Glyceraldhyde Phosphate Dehydrogenase (GPDH); a pair of primers (GenScript Corporation, U.S.A.) were used as forward and reverse primers, their sequences are shown in (Table 1).

3- Electrophoresis of PCR products. RT-PCR products were separated by electrophoresis on $2 \%$ agarose gel prepared in Tris Acetate EDTA electrophoresis buffer.

\section{Primer Sequence}

Amplified segment

Telomerase F 5 ' - CGG AAG AGT GTC TGG AGC AA - 3' 145 BP

Telomerase R 5' - GGA TGA AGC GGA GTC TGG A - 3'

Keratin 20 F $\quad 5^{\prime}$ - GAG GTT CAA CTA ACG GAG CT - 3' 253 BP

Keratin 20 R $55^{\prime}$ - TCT CTC TTC CAG GGT GCT TA - 3'

GPDH F $\quad 5^{\prime}$ - CCA TGG AGA AGG CTG GGG - 3' 208 BP

GPDH R 5' - CAA AGT TGT CAT GGA TGA CC - 3'

The following protocols were used for each of the cDNAs amplified:

$\begin{array}{llll}\text { Step } & \begin{array}{l}\text { Telomerase } \\ \& \text { GPDH }\end{array} & \text { Keratin } 20 & \text { Cycles } \\ \begin{array}{l}\text { Reverse } \\ \text { transcription }\end{array} & 30 \text { min at } 42^{\circ} \mathrm{C} & & 1 \\ \text { cDNA } & 5 \text { min at } 95^{\circ} \mathrm{C} & & \\ \begin{array}{l}\text { Denaturation } \\ \text { Denaturation }\end{array} & 94^{\circ} \mathrm{C} \text { for } 45 \mathrm{sec} & 94^{\circ} \mathrm{C} \text { for } 1 \text { min } & 35 \text { cycles for } \\ \begin{array}{l}\text { Primer Annealing } \\ 60^{\circ} \mathrm{C} \text { for } 45 \mathrm{sec}\end{array} & 55^{\circ} \mathrm{C} \text { for } 2 \text { min } & \text { Telomerase and } \mathrm{GPDH} \\ \begin{array}{l}\text { Primer Extension } \\ 72^{\circ} \mathrm{C} \text { for } 90 \mathrm{sec}\end{array} & 72^{\circ} \mathrm{C} \text { for } 2 \text { min } & 40 \text { cycles for keratin20 } \\ \text { Final extension } & 10 \text { min at } 72^{\circ} \mathrm{C} & & 1\end{array}$

II- Urine cytology: The slides were fixed in 96\% ethyl alcohol and subjected to Hematoxylin and Eosin Staining.

III- Immunohistochemical staining: Slides of exfoliated cells sedimented in urine were prepared, fixed and stained with mouse anti-keratin 20 antibody and visualized by Anti- polyvalent/HPR/DAB Detection System (Spring Biosciences, Fremont, CA).

IV- Bacterial culture: $10 \mu \mathrm{l}$ of urine were inoculated into blood agar and MacConkey agar plates, incubated for $24 \mathrm{~h}$ in $37^{\circ} \mathrm{C}$ then the colonies were identified using API system Viable count was done by the method of El Salahy [29].

V- Dielectric Properties of DNA: DNA isolation Kit supplied by Qiagen (cat. No. 51306) used to extract DNA from urine sample. The concentration of the DNA for all samples estimated is diluted in sterilized water to below $1 \%$.

\section{Dielectric measurement}

Dielectric measurements were run in the frequency range from 0.1 to $10 \mathrm{MHz}$ using a loss factor meter type $1033 \mathrm{RFT}$ (Verlustfaktor Messgerkt Funkwerk, Erfut, Germany). During measurements the sample with the cell was kept at $20 \pm 0.1 \mathrm{C}$ in a temperature-controlled incubator (Type 2771 Kölermann, Germany). The measured values of capacitance $(\mathrm{C})$ and resistance $(\mathrm{R})$ were used to calculate the real, $\varepsilon^{\prime}$, and imagenary, $\varepsilon^{\prime \prime}$, part of the complex permittivity $\varepsilon^{*} ; \varepsilon^{*}=\varepsilon^{\prime}-\phi \varepsilon^{\prime \prime}$, using the following equations:

i) $\varepsilon^{\prime}=\varepsilon_{\mathrm{o}} \mathrm{C} \mathrm{k}, \mathrm{k}=1 \mathrm{~cm}^{-1}$ (cell constant that depends on the cell dimensions) ii) Loss tangent: $\tan \delta=\varepsilon^{\prime \prime} / \varepsilon^{\prime}=1 / 2 \pi \mathrm{f}$ R so $\varepsilon^{\prime \prime}=\varepsilon^{\prime} \tan \delta$

iii) The Conductivity $\sigma=\mathrm{k} / \mathrm{R}\left(\Omega^{-1} \mathrm{~m}^{-1}\right)$

iv) Relaxation Time $\tau=1 / 2 \pi f \mathrm{c}, \mathrm{fc}$ is the critical frequency corresponding to the midpoint of the dispersion curve.

v) The plot $\varepsilon$ ' vs $\varepsilon$ "' (Cole - Cole plot) will produce a circle of radius $1 / 2\left(\varepsilon_{0}+\varepsilon_{\infty}\right)$

vi) It was shown by Cole and Cole that the angle $\theta=\alpha \pi / 2$. This in turn enable to estimate the Cole and Cole parameter, $\alpha$, experimentally, so $\alpha=2 \theta / \pi$.

vii) Complex permittivity. The dielectric dispersion $(\Delta \dot{\varepsilon})$ was calculated by applying the relation. $\Delta \dot{\varepsilon}=\varepsilon_{\mathrm{s}}-\varepsilon_{\infty}$

\section{Statistical analysis}

The statistical methods and analysis for evaluation of the results were done by calculating arithmetic means and standard deviations for the malignant, benign and control groups and dielectric measurements. All these measurements had been done for all groups reading of the three runs was used to calculate the means and standard deviations for each group. The Mann-Whitney U-test was used to determine the significant differences among values of different groups. A $\mathrm{P}<0.05$ was considered significant.

\section{Results}

Figure 1 represents examples for the RT-PCR results of (a) $253 \mathrm{bp}$ band of K 20, (b) $145 \mathrm{bp}$ band of telomerase and (c) $208 \mathrm{bp}$ band of GPDH.

Figure 2 shows positive cytoplasmic K20 staining of malignant cells in urine cytology in a case of TCC and the H \& E staining of the same case.

Figure 3 shows positive deep cytoplasmic staining with K 20 antibody of malignant cells in urine cytology in a case of SCC and the $\mathrm{H} \& \mathrm{E}$ staining of the same case.

Figure 4 illustrates the variation of the permittivity and dielectric loss $\left(\varepsilon\right.$ and $\left.\varepsilon^{\prime \prime}\right)$ plotted on the left y axis and the conductivity $(\sigma)$ plotted on the right $\mathrm{y}$ axis as a function of the frequency for DNA suspension

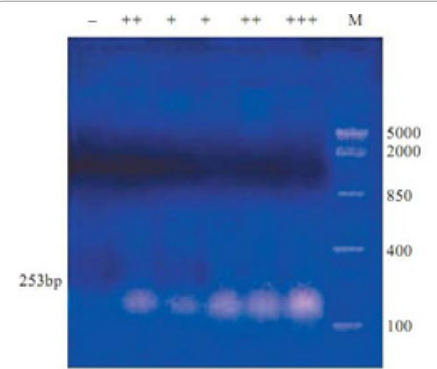

(A)

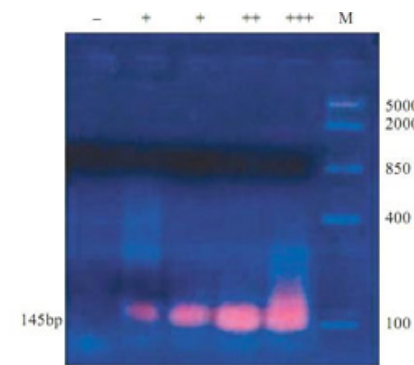

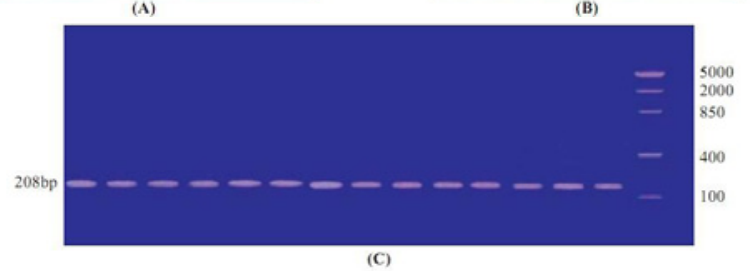

Figure 1: Representative RT-PCR results analysis for (A) 253bp band of K20, (B) $145 \mathrm{bp}$ band of Telomerase and (C) $208 \mathrm{bp}$ band of GPDH. M: DNA size marker $100 \mathrm{bp}$. 
Citation: Ibrahim FF, Ghannam MM (2012) The Diagnostic Potential of Dielectric Properties, Telomerase Activity and Cytokeratin 20 in Urine Cells of Bladder Cancer Patients. J Cancer Sci Ther 4: 237-242. doi:10.4172/1948-5956.1000148

of control group and for DNA suspension of malignant group (hollow symbol) respectively. It is clear from the figures that $\varepsilon$ passed through a dielectric dispersion in the frequency range demonstrated and the decrease in the values of $\varepsilon$ was accompanied by an increase in the values of conductivity which is a confidence in dielectric measurements [26]. This strong dielectric dispersion in the $\beta$ region $(0.1-10 \mathrm{MHz})$ for the samples is mainly due to protein and/or DNA, and counter ion molecular relaxation [23].

The results also indicate that the values of $\Delta \boldsymbol{\epsilon}^{\prime}$ and $\sigma$ are much higher for malignant group than normal group. Figure 5 shows the dielectric relaxation characteristics of benign group as compared with normal group. The results indicate pronounced changes in the values of $\Delta \varepsilon^{\prime}$ and $\sigma$ for the samples from benign group approximately similar to normal tissue. The values of $\Delta \varepsilon^{\prime}, \sigma$, relaxation time $(\tau)$ and Cole-Cole parameter $(\alpha)$ were calculated for DNA suspension samples from all groups and the average values were considered and given in Table 1.

\section{Discussion}

Bladder cancer has always received much attention in Egypt due to its high prevalence, with high mortality rates and the distinct pattern that was different from that reported in western countries [27].

Cystoscopic evaluation forms the basis of bladder cancer diagnosis and staging. Cystoscopy has a number of disadvantages such as the discomfort, risk of urinary tract infection, pain and cost. In addition, it fails to detect dysplasias and Carcinoma In Situ (CIS). All this makes cystoscopy unsuitable for screening [1].

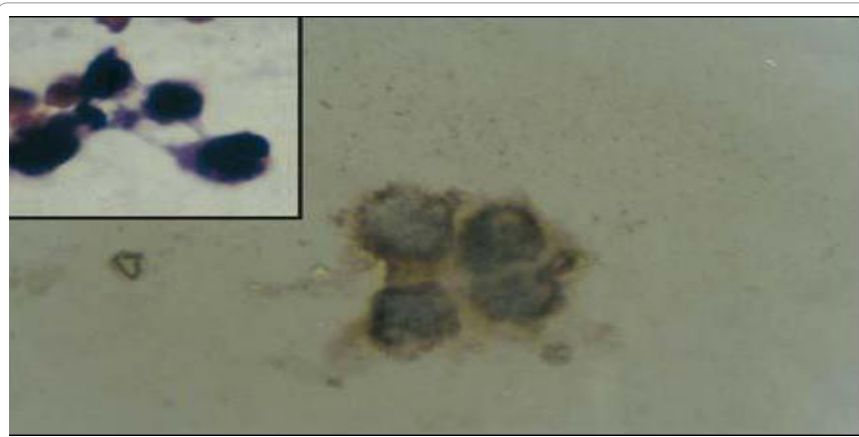

Figure 2: Positive cytoplasmic K20 staining of malignant cells in urine cytology in Case of TCC. (K20 IHC:100).

In set: Malignant cells in the same case of TCC in urine (H\&E:100)

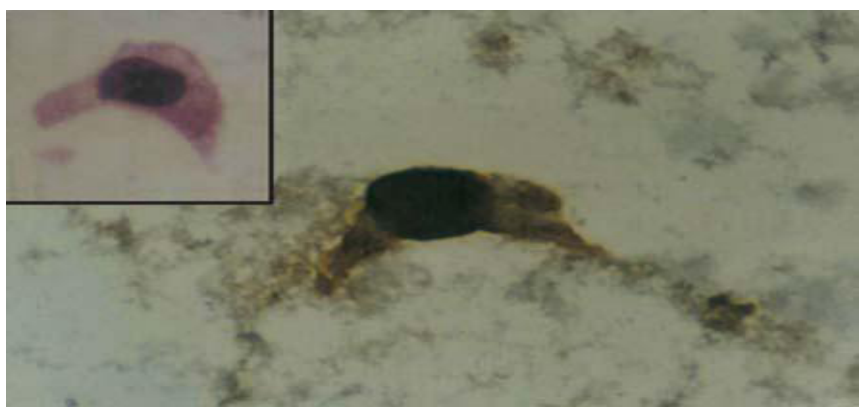

Figure 3: Positive deep cytoplasmic staining of malignant cells in urine cytology in a case of SCC (K20 IHC: 100).

In set: Malignant cells in the same case of SCC in urine (H\&E: 100).

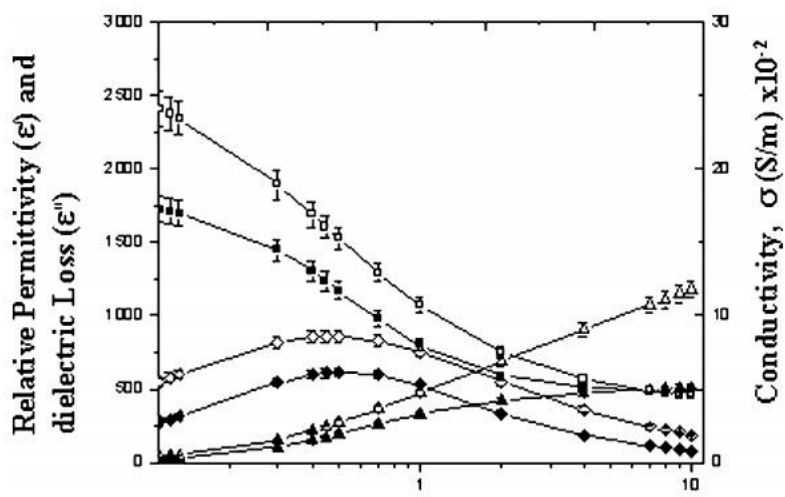

Frequency (MHz)

Figure 4: The variation of the relative permittivity $\boldsymbol{\epsilon}^{\prime}(\mathbf{\bullet})$, dielectric loss $\boldsymbol{\varepsilon}^{\prime}(\bullet)$ (left scale) and the electric conductivity $\sigma(\boldsymbol{\Delta})$ (right scale) as a function of the applied frequency in the range of $0.1-10 \mathrm{MHz}$ for DNA suspension of control group (solid symbol), and for DNA suspension of malignant group (hollow symbol).

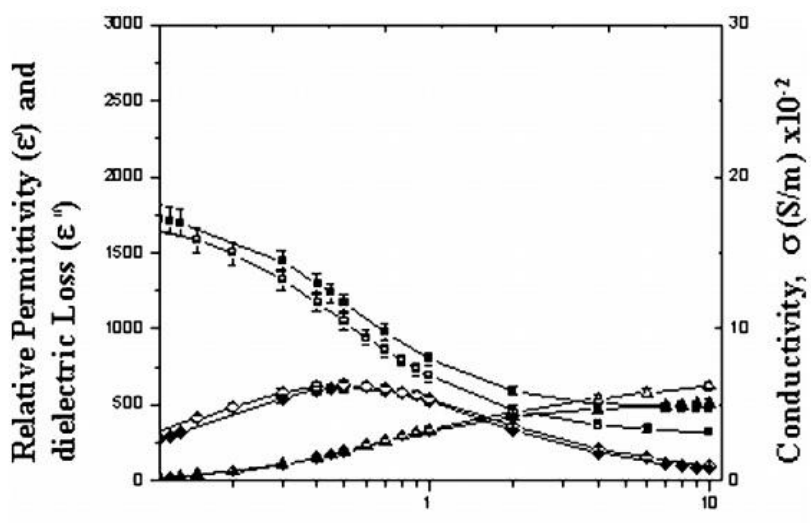

Frequency (MHz)

Figure 5: The variation of the relative permittivity $\boldsymbol{\epsilon}^{\prime}(\mathbf{\bullet})$, dielectric loss $\boldsymbol{\varepsilon}^{(\bullet)}$ (left scale) and the electric conductivity $\sigma(\boldsymbol{\Delta})$ (right scale) as a function of the applied frequency in the range of $0.1-10 \mathrm{MHz}$ for a DNA suspension of control group (solid symbol), and for DNA suspension of benign group (hollow symbol).

\begin{tabular}{|c|c|c|c|c|}
\hline Pram. Sample & $\Delta \varepsilon^{\prime}$ & $\mathrm{T}(\mu \mathrm{s})$ & $\sigma(\Omega \mathrm{m})^{-1}$ & $\alpha$ \\
\hline Control & $1254 \pm 35$ & $0.30 \pm 0.010$ & $4.90 \pm 0.22$ & $0.05 \pm 0.01$ \\
\hline Malignant & $1979 \pm 44$ & $0.34 \pm 0.012$ & $11.50 \pm 0.33$ & $0.20 \pm 0.02$ \\
\hline Benin & $1344 \pm 37$ & $0.32 \pm 0.011$ & $6.24 \pm 0.25$ & $0.11 \pm 0.01$ \\
\hline
\end{tabular}

Table 1: The values of $\Delta \varepsilon^{\prime}, \sigma$, relaxation time ( $\mathrm{T}$ ) and Cole-Cole parameter $(\alpha)$ for DNA suspension samples.

The golden marker for bladder cancer screening is still urinary cytology, as it is non-invasive, safe and inexpensive. It depends on the microscopic examination of urine sediments, to search for the probable presence of malignant cells [27]. Our results for urine cytology are comparable to those reported in literature. The specificity of this method was $100 \%$, and when it came to sensitivity, it was only $50 \%$.

The very low sensitivity of urine cytology renders its results inconclusive when it was used for screening for the presence of bladder cancer. All this calls for the search for new non-invasive markers for the detection of bladder cancer which should be specific, sensitive, reproducible, uninvasive and at acceptable cost. 


\section{Keratin 20}

K20 was measured by RT-PCR and by immunohistochemical staining of tumor cells shed in urine of bladder cancer patients. RTPCR method as expected is reflecting much higher sensitivity and specificity than immunostaining. RT-PCR had a general sensitivity of $80 \%$ and specificity of $86 \%$, while immunostaining showed $58 \%$ sensitivity and $80 \%$ specificity. In the study conducted by Southgate and Harnden [28] a much higher sensitivity and lower specificity for RT-PCR have been reported (sensitivity was $91 \%$ and specificity was $67 \%)$. On the other hand, K20 immunostaining reflected better results than urine cytology with a higher sensitivity (58\%vs. 50\%), especially in low-grade tumors, where cytology failed to detect malignancy, immunostaining gave better results.

K20 over expression was more prevalent in SCC patients (86.7\%) than in TCC patients $(77.1 \%)$. These results were in agreement with the results of El Salahy [29] who reported a similar profile with higher prevalence of K20 over expression in SCC than in TCC. However contradictory results were reported by Gee et al. [30] who claimed all SCC bladder tumors to be lacking K20 expression.

There was no statistically significant difference between TCC and SCC of the bladder, which reflects the inability of K20 as a tumor marker to differentiate the two types.

K20 expression showed no correlation with the grade of the disease in bladder TCC and SCC. Others had reported a correlation of K20 with grade in TCC and in SCC [28,31] a correlation that was missing in our study.

In a study by Golijanin et al. [32] that aimed to evaluate K20 immunostaining for bladder cancer diagnosis, it resulted in $81.6 \%$ sensitivity which was much higher than the sensitivity reported in our study (58\%) and $77 \%$ specificity that was close to that recorded in the current study (80\%).

When comparing RT-PCR and immunostaining of K20 as a bladder cancer detection techniques, immunostaining has two major advantages of lower cost and high specificity, opposed by non-reproducibility, low sensitivity and inherent technical risks as background staining which could result in false positive results. On the other hand, RT-PCR carries the advantages of high sensitivity and reproducibility with the disadvantage of high cost.

\section{Telomerase}

In our study, telomerase was expressed in a high percent of the malignant group, with an overall sensitivity of $82 \%$ and specificity of only $66 \%$. The sensitivity and specificity detected in our study were much lower than those reported in literature, where sensitivity ranged from $86 \%$ to $95.7 \%$ and specificity from $90 \%$ to $100 \%[33,34]$

In our results, there was a high positive prevalence in patients of the benign group, which greatly reduced the specificity of the assay. This high positive rate in the benign group is most probably due to haematuria and Inflammation. Since leukocytes, whether from blood in urine or from inflammatory reaction at the bladder, express telomerase and that expression is most probably the source of the positive results rather than the epithelial bladder cells.

The studied parameters (K20, Telomerase and cytology) are presented in (Table 2). In all parameters the malignant group was significantly different from both the benign and the control groups. In telomerase, the benign group was also significantly different from the control group. None of the three - studied parameters was correlated to stage of the disease. The RT-PCR data of telomerase and keratin 20 are represented in (Figure 6).

\section{Dielectric properties}

The dielectric properties of a DNA suspension of control group and DNA suspension of malignant group shown in (Figure 4) indicated that electric conductivity and permittivity have much higher values in DNA of malignant patients than of normal DNA (Table 1). These data are in agreement with Surowiec who reported that both permittivity and conductivity of breast carcinoma tissues (20-100 MHz) were higher than those of normal breast tissues [35].

It is well known that the dielectric dispersion in the frequency range $0.1 \mathrm{MHz}-10 \mathrm{MHz}$ for biological cells is mainly due to counterion polarization [23]. Therefore the increased values of permittivity and conductivity for malignant DNA suspension, as compared with normal DNA suspension, indicate larger increase of the counter ion molecules intensities for malignant DNA and hence increase the whole surface charge and charge distribution [23]. The pronounced decrease in counter-ion molecule intensities and the values of dielectric increment, permittivity, and conductivity, may be a result of changes in the metabolic functions of DNA benign group.

\section{Conclusion}

In conclusion, $\mathrm{K} 20$ is the best candidate for screening tests for bladder cancer, representing the highest sensitivity and specificity. Meanwhile, though telomerase was a sensitive enough marker, it reflected a high false positive rate that could put at risk its validity for screening of bladder cancer. K20 immunostaining gave much better results than standard urine cytology, so K20 IHC can replace urine cytology as a bladder cancer screening test. Dielectric properties of DNA may be used as an effective method for detecting malignant tumors.

\begin{tabular}{|c|c|c|c|c|c|c|c|}
\hline \multirow[t]{2}{*}{ Object } & \multicolumn{3}{|c|}{ K20 } & \multicolumn{2}{|c|}{ Telomerase } & \multirow[t]{2}{*}{ Cytology } & \multirow{2}{*}{$\begin{array}{l}\text { Bacterial } \\
\text { Infection }\end{array}$} \\
\hline & RT - & PCR & $\mathrm{IHC}$ & & & & \\
\hline & $M \pm S E(A U)$ & $\%>U L$ & $\%$ Positive & $\mathrm{M} \pm \mathrm{SE}(\mathrm{AU})$ & $\%>$ UL & $\%$ Positive & $\%$ Positive \\
\hline Control & $14.3 \pm 1.5$ & $1 / 156.7 \%$ & $0 \%$ & $29.3 \pm 5.9$ & $2 / 1513.3 \%$ & $0 / 150 \%$ & $1 / 156.7 \%$ \\
\hline Benign & $13.8 \pm 0.8$ & $4 / 2020 \%$ & $20 \%$ & $61.8 \pm 8.5^{\star}$ & $14 / 2046.7 \%$ & $0 / 200 \%$ & $10 / 2033.3 \%$ * \\
\hline Malignant & $27.5 \pm 1.6^{\star} \#$ & $40 / 4589 \%$ & $26 / 4558 \%$ & $117 \pm 10.3^{*} \#$ & $39 / 4587 \%$ & 23/45 $51 \%{ }^{*} \#$ & $33 / 45$ 73.3\%*\# \\
\hline TCC & $27.8 \pm 2.6^{*} \#$ & $25 / 3083.3 \%$ & $13 / 3043.3 \%$ & $111.6 \pm 14^{*} \#$ & $23 / 3077 \%$ & 16/30 53.3\%*\# & $21 / 3070 \% * \#$ \\
\hline SCC & $28.4 \pm 3.1^{*} \#$ & $13 / 1586.7 \%$ & $6 / 1540 \%$ & $124.9 \pm 16^{*} \#$ & $14 / 1593.3 \%$ & $6 / 1540 \% * \#$ & $12 / 1580 \%{ }^{*} \#$ \\
\hline
\end{tabular}

* Compared to control group, \# Compared to benign group, Significant when $p<0.05$

$\%>$ Upper limit = patient number more than $20 \mathrm{AU}$ for K20 and 30AU for Telomerase.

Table 2: Percent positivity of all parameters and the difference between all groups. 
Citation: Ibrahim FF, Ghannam MM (2012) The Diagnostic Potential of Dielectric Properties, Telomerase Activity and Cytokeratin 20 in Urine Cells of Bladder Cancer Patients. J Cancer Sci Ther 4: 237-242. doi:10.4172/1948-5956.1000148

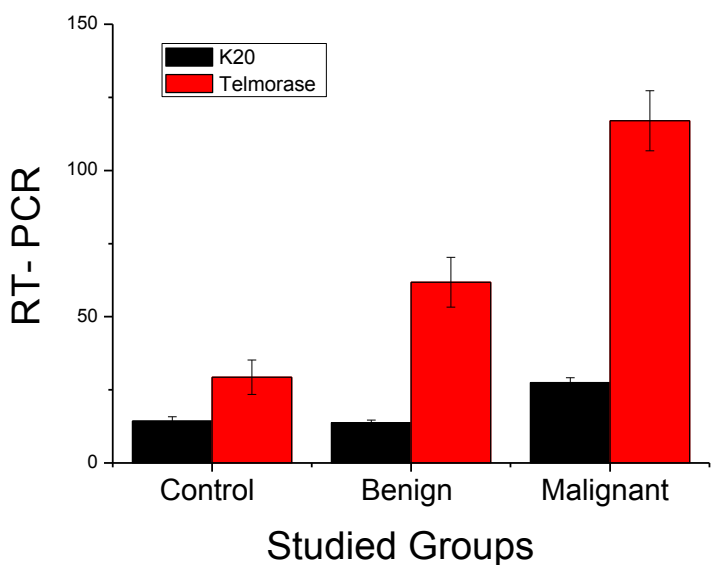

Figure 6: RT-PCR comparison data of telomerase and keratin 20 .

It can be used with the combination of such molecular techniques to facilitate and improve early diagnosis of bladder carcinoma.

\section{References}

1. Scher HI, Shipley WU, Herr HW (1997) Cancer of the bladder. In, De Vita VT, Hellman S, Rosenberg SA (Eds), Cancer: Principles and practice of oncology. (15thedn), New York: Lippincott-Raven 1300-1321.

2. Madeb R, Messing EM (2004) Gender, racial and age differences in bladder cancer incidence and mortality. Urol Oncol 22: 86-92.

3. Barlandas-Rendon E, Muller MM, Garcia-Latorre E, Heinschink A (2002) Comparison of urine cell characteristics by flow cytometry and cytology in patients suspected of having bladder cancer. Clin Chem Lab Med 40: 817-823.

4. McEachern MJ, Krauskopf A, Blackburn EH (2000) Telomeres and their control. Annu Rev Genet 34: 331-358.

5. Allsopp RC, Vaziri H, Patterson C, Goldstein S, Younglai EV, et al. (1992) Telomere length predicts replicative capacity of human fibroblasts. Proc Natl Acad Sci USA 89: 10114-10118.

6. Shay JW, Bacchetti S (1997) A survey of telomerase activity in human cancer. Eur J Cancer 33: 787-791.

7. Chatziantoniou VD (2001) Telomerase: Biological Function and Potential Role in Cancer Management. Pathol Oncol Res 7: 161-170.

8. Meyerson M (2000) Role of telomerase in normal and cancer cells. J Clin Oncol 18: 2626-2634.

9. Erdem E, Dikmen G, Atsu N, Dogan P, Ozen H (2003) Telomerase activity in diagnosis of bladder cancer. Scand J Urol Nephrol 37: 205-209.

10. Li Z, Kong C, Wang P, Liu X, Liu T (2002) Telomerase activity in urine in diagnosis and recurrence surveillance of urothelial carcinoma. Chin Med $J$ (Engl) 115: 1650-1652.

11. Sanchini MA, Bravaccini S, Medri L, Gunelli R, Nanni O, et al. (2004) Urine telomerase: An important marker in the diagnosis of bladder cancer. Neoplasia 6: 234-239.

12. Isurugi K, Suzuki Y, Tanji S, Fujioka T (2002) Detection ofthe presence of catalytic subunit mRNA associated with telomerase gene in exfoliated urothelial cells from patients with bladder cancer. J Urol 168: 1574-1577.

13. Coulombe PA, Ma L, Yamada S, Wawersik M (2002) Intermediate filaments at a glance. J Cell Sci 114: 4345-4347.

14. Eichner R, Bonitz P, Sun TT (1984) Classification of epidermal keratins according to their immunoreactivity, isoelectric point, and mode of expression. J Cell Biol 98: 1388-1396.

15. Fuchs E, Weber K (1994) Intermediate filaments: structure, dynamics, function, and disease. Annu Rev Biochem 63: 345-382.

16. Rugg EL, Leigh IM (2004) The keratins and their disorders. Am J Med Genet C Semin Med Genetec: 4-11.

17. Moll R, Schiller D, Franke WW (1990) Identification of protein IT of the intestinal cytoskeleton as a novel type I cytokeratin with unusual properties and expression patterns. J Cell Biol 111: 567-580.

18. Zhou Q, Toivola DM, Feng N, Greenberg HB, FrankeWW, et al. (2003) Keratin 20 helps maintain intermediate filament organization in intestinal epithelia. Mo Biol Cell 14: 2959-2971.

19. Alsheikh A, Mohamedali Z, Jones E, Masterson J, Gilks CB (2001) Comparison of the WHO/ISUP Classification and Cytokeratin 20 Expression in Predicting the Behavior of Low-Grade Papillary Urothelial Tumors. Mod Pathol 14: $267-$ 272.

20. Bae JW, Choi KH, Kim HG, Park SH (2000) The detection of circulating breast cancer cells in peripheral blood by reverse transcriptase polymerase chain reaction. J Korean Med Sci 15: 194-198.

21. Rosenberg R, Hoos A, Mueller J, Baier P, Stricker D, et al. (2002) Prognostic Significance of Cytokeratin-20 Reverse Transcriptase Polymerase Chain Reaction in Lymph Nodes of Node-Negative Colorectal Cancer Patients. J Clin Oncol 20: 1049-1055.

22. Christoph F, Muller M, Schostak M, Soong R, TabitiK, et al. (2004) Quantitative detection of cytokeratin 20 mRNA expression in bladder carcinoma by real-time reverse transcriptase-polymerase chain reaction. Urology 64: 157-161.

23. Polk C, Postow E (1966) Hand book of biological effect of electromagnetic fields. ( $\left.2^{\text {nd }} E d n\right)$, CRC Press 25-102.

24. Ghannam MM, El-Gebaly RH, Gaber MH, Ali FM (2002) Inhibition of Ehrlich tumor growth in mice by electric interference therapy (in vivo studies). Electromagn Biol Med 21: 255-268.

25. Fadel MA, El-Gebaly RH, Aly AA, Ibrahim FF (2005) Control of Ehrlich tumor growth by electromagnetic waves at resonance frequency (in vivo studies) Electromagn Biol Med 24: 9-21.

26. De L Kronig R (1926) On the theory of dispersion of x-rays. J Opt So Am 12 547-556.

27. Soliman AS, Levin B, El-Badawy S, Nasser SS, Raouf AA, et al. (2001) Planning cancer prevention strategies based on epidemiologic characteristics: an Egyptian example. Public Health Rev 29: 1-11.

28. Southgate J, Harnden P (1999) Re: Cytokeratin 20: A new marker for early detection of bladder cell carcinoma. J Urol 162: 501-502.

29. El-Salahy EM (2002) Evaluation of cytokeratin-19 \& cytokeratin-20 and interleukin-6 in Egyptian bladder cancer patients. Clin Biochem 35: 607-613.

30. Gee JR, Montoya RG, Khaled HM, Sabichi AL, Grossman HB (2003) Cytokeratin 20, AN43, PGDH, and COX-2 expression in urothelial and squamous cell carcinoma of the bladder. Urol Oncol 21: 266-270.

31. Christoph F, Muller M, Schostak M, Soong R, Tabiti K, et al. (2004) Quantitative detection of cytokeratin 20mRNA expression in bladder carcinoma by real-time reverse transcriptase-polymerase chain reaction. Urology 64: 157-161.

32. Golijanin D, Shapiro A, Pode D (2000) Immunostaining of cytokeratin 20 in cells from voided urine for detectionof bladder cancer. J Urol 164: 1922-1925.

33. Melissourgos N, Kastrinakis NG, Davilas I, Foukas $P$, Farmakis A, et al. (2003) Detection of human telomerase reverse transcriptase mRNA in urine of patients with bladder cancer: evaluation of an emerging tumor marker. Urology 62: $362-367$

34. Yokota K, Kanda K, Inou Y, Kanayama H, Kagawa S (1998) Semi-quantitative analysis of telomerase activity in exfoliated human urothelial cells and bladder transitional cell carcinoma. Br J Urol 82: 727-732.

35. Surowiec AJ, Stuchly SS, Barr JB, Swarup A (1988) Dielectric properties of breast carcinoma and the surrounding tissues. IEEE Trans Biomed Eng 35: 257-263. 